5. Mason RJ, Moazzez A, Sohn H, Katkhouda N. Metaanalysis of randomized trials comparing antibiotic therapy with appendectomy for acute uncomplicated (no abscess or phlegmon) appendicitis. Surg Infect (Larchmt). 2012; 13(2):74-84.

6. Hall NJ, Eaton S, AbboO, Arnaud AP, et al. Appendectomy versus non-operative treatment for acute uncomplicated appendicitis in children: study protocol for a multicentre, open-label, non-inferiority, randomised controlled trial. BMJ Paediatr Open. 2017; 1(1):e000028.

7. Rollins KE, Varadhan KK, Neal KR, Lobo DN. Antibiotics versus appendicectomy for the treatment of uncomplicated acute appendicitis: anupdated meta-analysis of randomized controlled trials. World J Surg. 2016; 40(10):2305-18.

8. Caruso AM, Pane A, Garau R, Atzori P, et al. Acute appendicitis in children: not only surgical treatment. $J$ Pediatr Surg. 2017; 52(3):444-8.

9. Marzuillo P, Germani C, Krauss BS, Barbi E. Appendicitis in children less than five years old: a challenge for the general practitioner. World J Clin Pediatr. 2015; 4(2):19-24.

10. Bachur RG, Lipsett SC, Monuteaux MC. Outcomes of Nonoperative Management of Uncomplicated Appendicitis. Pediatrics. 2017; 140(1):e20170048.

\title{
Pacifiers: Counseling instead of prohibiting. The new Baby- friendly Hospital Initiative
}

\section{The beginning}

The first few hours and days of a newborn's life are a critical window for establishing lactation and for providing mothers with the support they need to breastfeed successfully. Breast milk is considered the biological norm to feed the baby and a preventive action for both the mother (cancer) and the infant (infections).

The joint World Health Organization (WHO)/ United Nations International Children's Emergency Fund (UNICEF) statement (Geneva, 1989) urged all mother and child health care services to implement the measures summarized in the "Ten Steps to Successful Breastfeeding."1

One year later, the "Innocenti Declaration" was launched after a meeting held at the Ospedale degli Innocenti, Florence, Italy. The declaration made a strong appeal to governments worldwide to support breastfeeding through programs and legislation, such as breastfeeding rights of working women, and prioritized the implementation of the "Ten Steps to Successful Breastfeeding." ${ }^{2}$

\section{Baby-friendly Hospital Initiative}

Both statements may be considered the immediate precedent of the Baby-friendly Hospital Initiative (BFHI). The BFHI establishes that the Ten Steps to Successful Breastfeeding are mandatory at the hospitals certified as babyfriendly by the UNICEF.

It is estimated that, at present, only $10 \%$ of births worldwide take place at facilities that have been designated as baby-friendly hospitals according to the BFHI. ${ }^{3}$ Although it has been demonstrated that the program promotes breastfeeding among mothers with a low level of education, ${ }^{4}$ it has met with criticism in terms of its difficult sustainability. The vertical enforcement of recommendations has also been questioned. These considerations were outlined in the Executive Summary of the new BFHI implementation guidance. ${ }^{3}$

I personally believe that the original Step 9 "Give no artificial teats or pacifiers (also called dummies or soothers) to breastfeeding infants" was worded this way due to the prevalence of fundamentalism over science, which had been adopted by certain professional associations that had managed to institutionalize a strict and unyielding behavior in relation to breastfeeding that took form throughout child care settings.

Such stance was sustained at a time when the percentage of exclusively breastfed infants was really small, which resulted in a high infant morbidity and mortality (gut microbiota alteration and milk contamination). This way, breastfeeding advocacy became a life-saving intervention.

The recommendation against the use of pacifiers was based on alleged risk factors that were not confirmed in randomized controlled trials, which is the best evidence to assess a health intervention. ${ }^{5}$ Step 9, as it was written in 1989, constitutes the unethical dogma of breastfeeding ${ }^{6}$ because it has been demonstrated that pacifiers during the baby's sleep time reduce the risk for sudden infant death syndrome. ${ }^{7}$ At the time the Ten Steps were developed, there was no epidemiological evidence showing that pacifier use was harmful for breastfeeding. It is worth noting that Victora et al. published the 
first observational study that concluded that there was a causal association between pacifiers and weaning. The publication was made in The Lancet in $1993,{ }^{8}$ that is to say, four years after the Ten Steps were written. Investigations continued, and four other randomized trials revealed that there were no differences between breastfeeding outcomes and different pacifier use scenarios: preterm infants, ${ }^{9}$ healthy newborn infants after 15 days of life, ${ }^{10}$ at BFHI member hospitals, ${ }^{11}$ and after educational programs that emphasized pacifier prohibition. ${ }^{12}$ In this regard, a Cochrane analysis was published in 2016 that concluded that pacifier use in healthy term infants since the moment of birth or once breastfeeding was established did not significantly affect the prevalence or duration of exclusive and partial breastfeeding until four months old. ${ }^{7}$

\section{The modification: a friendlier change for babies}

In 2015, the WHO and the UNICEF launched a process for the reassessment and reinforcement of the BFHI program: case studies, interviews with key informants, an overall policy survey, and bibliographic reviews to better understand the initiative's status and impact. A literature systematic review was performed that carefully examined the evidence for each of the Ten Steps. Ultimately in April 2018, the WHO and the UNICEF published the final version of the Implementation guidance: Protecting, promoting and supporting breastfeeding in facilities providing maternity and newborn services: the revised Babyfriendly Hospital Initiative $2018 .^{3}$

The document presents the first review of the Ten Steps since their publication in 1989 (Table 1). The topic of Step 9 is still the same but it has been updated according to evidencebased medicine guidelines and the worldwide public health policy: "Counsel mothers on the use and risks of feeding bottles, teats and pacifiers." ${ }^{3}$ Such modification is a paradigm shift that allows families to make informed decisions on the use or avoidance of pacifiers. It paves the way for physicians, nurses, and health care staff in general to continue supporting breastfeeding without avoiding an adequate recommendation of pacifier use when putting the baby to sleep, an intervention that has clearly demonstrated to reduce the risk for sudden infant death syndrome. For mothers who cannot or do not wish to breastfeed, this change reverts the dogma and alleviates the guilt by offering a broader spectrum of options.

TABLE 1. The Ten Steps to Successful Breastfeeding (Geneva 1989) and WHO (2018)

\begin{tabular}{|c|c|}
\hline Ten Steps 1989 & Ten Steps 2018 \\
\hline 1. Have a written breastfeeding policy. & $\begin{array}{l}\text { 1. Have institutional procedures necessary to ensure that } \\
\text { care is delivered consistently and ethically. }\end{array}$ \\
\hline $\begin{array}{l}\text { 2. Train all health care staff in skills necessary to implement } \\
\text { this policy. }\end{array}$ & $\begin{array}{l}\text { 2. Ensure that staff have sufficient knowledge, competence } \\
\text { and skills to support breastfeeding. }\end{array}$ \\
\hline $\begin{array}{l}\text { 3. Inform all pregnant women about the benefits and } \\
\text { management of breastfeeding. }\end{array}$ & $\begin{array}{l}\text { 3. Discuss the importance and management of breastfeeding } \\
\text { with pregnant women and their families. }\end{array}$ \\
\hline $\begin{array}{l}\text { 4. Help mothers initiate breastfeeding within the } \\
\text { first hour of birth. }\end{array}$ & $\begin{array}{l}\text { 4. Facilitate immediate and uninterrupted skin-to-skin contact } \\
\text { and support mothers to initiate breastfeeding as soon as } \\
\text { possible after birth. }\end{array}$ \\
\hline $\begin{array}{l}\text { 5. Show mothers how to breastfeed and how to } \\
\text { maintain lactation, even if they should be separated } \\
\text { from their infants. }\end{array}$ & $\begin{array}{l}\text { 5. Support mothers to initiate and maintain breastfeeding } \\
\text { and manage common difficulties. }\end{array}$ \\
\hline $\begin{array}{l}\text { 6. Give newborn infants no food or drink other than } \\
\text { breast milk, unless medically indicated. }\end{array}$ & $\begin{array}{l}\text { 6. Do not provide breastfed newborns any food or fluids } \\
\text { other than breast milk, unless medically indicated. }\end{array}$ \\
\hline $\begin{array}{l}\text { 7. Practice rooming-in (allow mothers and infants } \\
\text { to remain together) } 24 \text { hours a day. }\end{array}$ & $\begin{array}{l}\text { 7. Enable mothers and their infants to remain together } \\
\text { and to practice rooming-in } 24 \text { hours a day. }\end{array}$ \\
\hline 8. Encourage breastfeeding on demand. & $\begin{array}{l}\text { 8. Support mothers to recognize and respond to their infants' } \\
\text { cues for feeding. }\end{array}$ \\
\hline $\begin{array}{l}\text { 9. Give no artificial teats or pacifiers (also called } \\
\text { dummies or soothers) to breastfeeding infants. }\end{array}$ & $\begin{array}{l}\text { 9. Counsel mothers on the use and risks of feeding bottles, } \\
\text { teats and pacifiers. }\end{array}$ \\
\hline $\begin{array}{l}\text { 10. Foster the establishment of breastfeeding support } \\
\text { groups and refer mothers to them on discharge } \\
\text { from the hospital or clinic. }\end{array}$ & $\begin{array}{l}\text { 10. Coordinate discharge so that parents and their infants } \\
\text { have timely access to ongoing support and care. }\end{array}$ \\
\hline
\end{tabular}




\section{Acknowledgments:}

I would like to thank Néstor Vain, M.D., for making a critical review of the article.

Alejandro G. Jenik, M.D. Hospital Italiano de Buenos Aires E-mail address: alejandro.jenik@hospitalitaliano.org.ar

http: / / dx.doi.org/ 10.5546/ aap.2019.eng.70

To cite: Jenik A. Pacifiers: Counseling instead of prohibiting. The new Baby-friendly Hospital Initiative. Arch Argent Pediatr 2019;117(2):70-72.

\section{REFERENCES}

1. OMS/UNICEF. Protección, promoción y apoyo de la lactancia natural: la función especial de los servicios de maternidad. Ginebra: OMS; 1989. [Accessed on: December 19th 2018 ] Available at: http: / / apps.who.int/ iris / bitstream/handle/10665/41246/9243561308_spa. pdf?sequence $=1$ \&isAllowed $=y$

2. UNICEF. Innocenti Declaration on the Protection, Promotion and Support of Breastfeeding. Florence, Italy: UNICEF; 1990. [Accessed on: December 19 $9^{\text {th }}, 2018$ ]. Available at:https:/ / www.unicef.org/spanish/nutrition/ index_24807.html?p=printme

3. UNICEF/WHO. Protecting, promoting and supporting breastfeeding in facilities providing maternity and newborn services: the revised Baby-friendly Hospital Initiative. Geneva: WHO; 2018. [Accessed on: December $20^{\text {th }}, 2018$ ]. Available at: https: / / www.who.int/ nutrition/ publications/infantfeeding/bfhi-implementation-2018.pdf

4. Patnode CD, Henninger ML, Senger CA, Perdue LA, Whitlock E. Primary Care Interventions to Support Breastfeeding: Updated Evidence Report and Systematic Review for the US Preventive Services Task Force. JAMA. 2016;316(16):1694-705.

5. Jenik AG, Vain N. The pacifier debate. Early Hum Dev. 2009;85(10 Suppl:S89-91.

6. Flaherman V, Von Kohorn I. Interventions Intended to Support Breastfeeding Updated Assessment of Benefits and Harms. JAMA. 2016;316(16):1685-7.

7. Jenik A. Pacifier Use and SIDS. In Cohen MC, Scheimberg I, Beckwith B, Hauck F. Investigation of Sudden Infant Death Syndrome. London: Cambridge University Press; 2019. [In press]

8. Victora CG, Tomasi E, Olinto MT, Barros FC. Use of pacifiers and breastfeeding duration. Lancet. 1993;341(8842):404-6.

9. Collins CT, Ryan P, Crowther CA, McPhee A, et al. Effect of bottles, cups, and dummies on breast feeding in preterm infants: a randomised controlled trial. BMJ. 2004;329(7459):193-8.

10. Jenik AG, Vain NE, Gorestein AN, Jacobi NE. Does the recommendation to use a pacifier influence the prevalence of breastfeeding? J Pediatr. 2009;155(3):350-4.

11. Schubiger G, Schwarz U, Tönz O. UNICEF/WHO baby-friendly hospital initiative: does the use of bottles and pacifiers in the neonatal nursery prevent successful breastfeeding? Neonatal Study Group. Eur J Pediatr.1997;156(11):874-7.

12. Kramer MS, Barr RG, Dagenais $S$, Yang H, et al. Pacifier use, early weaning, and cry / fuss behavior: a randomized controlled trial. JAMA. 2001;286(3):322-6. 